\title{
TEKNOLOJİ VE REKABETÇİLİK: TEMEL KAVRAMLAR VE ENDEKSLER BAĞLAMINDA BİR DEĞERLENDİRME ${ }^{1}$
}

\section{TECHNOLOGY AND COMPETITIVENESS: AN ASSESSMENT IN TERMS OF MAIN CONCEPTS AND INDEXES}

\author{
Prof. Dr. Yusuf BAYRAKTUTAN
}

Kocaeli Üniversitesi, İIBF, İktisat Bölümü, ybayraktutan@kocaeli.edu.tr

Dr. Hanife BIDIRDI

Kocaeli Üniversitesi, SBE, İktisat ABD hbidirdi@kocaeli.edu.tr

\section{$\ddot{O} \mathbf{z}$}

Hızlı ve kapsaml dönüşüm sürecinin yaşandığı günümüz dünya ekonomisinde ülkelerin rekabet güçleri, ileri teknolojiye dayalı yüksek katma değer taşlyan mal ve hizmet üretme kabiliyetlerinden etkilenmektedir. Teknolojinin üretim sürecine yansımalarl, genellikle araştırma-geliştirme (ar-ge) faaliyetlerinin bir çıktısı ve/veya yan ürünü mahiyetindedir. Dünya'da çeşitli kurumlar tarafindan belli göstergeler yardımıyla ve farkl yöntemler kullanılarak rekabet gücü ölçülmektedir. Bu ölçümlerelendekslere göre rekabetçilik sıralamasında önde gelen ülkelerin aynı zamanda ar-ge için daha fazla kaynak ayıran ve yeni teknolojiler geliștiren ülkeler olması, teknolojik gelişme ve rekabetçilik ilişsisinin açık bir göstergesidir. Teknolojik gelișme ilintili kanalların ișleyişi ile ülkelerin rekabetçilik sıralamasindaki konumu şekillenmektedir. Teknolojik gelişmenin rekabet gücü üzerindeki etkilerini, rekabetçilik endeksleri çerçevesinde değerlendirmeyi amaçlayan bu çalışmada öncelikle teknoloji, teknolojik gelişme ve rekabet gücü olgusu kavramsal çerçevede ele alınmış; daha sonra teknolojik gelişmenin rekabetçiliğe etkileri tartlşllarak Dünya Ekonomik Forumu (WEF) ve Uluslararası Yönetim Geliştirme Enstitüsü'nün (IMD), dünya ülkelerinin rekabetçilik bakımından konumlarını saptamak üzere geliştirdikleri endeksler bağlamında değerlendirme yapılmıs ve rekabet gücünü artırmaya yönelik politika önerileri paylaşılmıştır.

Anahtar Kelimeler: Teknolojik Gelişme, Rekabetçilik Endeksleri, Küresel Rekabetçilik Stralamast.

\footnotetext{
${ }^{1}$ Bu çalışma, Prof. Dr. Yusuf BAYRAKTUTAN danışmanlığında hazırlanan "Teknolojik Gelişme Dinamikleri ve İhracatın Niteliği: Panel Veri Analizi”" başlıklı doktora tezinden (Kocaeli Üniversitesi Sosyal Bilimler Enstitüsü, 2015) yararlanılarak hazırlanmıştır.
} 


\begin{abstract}
In today's global economy experiencing a rapid and comprehensive transformation process, competitiveness of countries have been affected by their ability to produce goods and services with high added value based on advanced technology. The reflection of technology on production process is usually resulted in the form of output and/or byproduct by using research and development (R\&D) activities. Competitiveness is measured by various organizations all over the world by using different methods and indicators. According to these measurements/indexes, the more a country invests on $R \& D$ and develops new technologies, the higher its ranking of competitiveness will be. This is a clear indicator of the relationship between technological progress and competitiveness. The competitive position of a country is shaped by the functioning of technological development channels. The main purpose of this study is to assess the effects of technological improvements on competitive power in terms of competitiveness indexes under the conceptual framework of technology, technological development and competitive power. In addition to that the effect of technological progress on competitiveness is also discussed and finally the competitive position of countries evaluated in terms of the indexes developed by World Economic Forum (WEF) and International Institute for Management Development (IMD), plus some policy proposals are presented.
\end{abstract}

Keywords: Technological Progress, Competitiveness Indexes, Rankings of Global Competitiveness.

\title{
1. GİRIȘ
}

Yoğunlaşan uluslararası etkileşim ortamında bir ülkenin küresel rekabet gücü, faktör donanımı ötesinde teknoloji düzeyi, teknoloji geliştirme ve yenilik üretme kapasitesi ve beşeri sermaye gibi nitelikleriyle yakından ilişkilidir. Teknolojik gelişmelerle birlikte süreklilik arz eden bir süreç olarak yeniden yapılanma, bilginin ve bilgiye dayalı teknolojilerin (mikro elektronik, enformasyon, iletişim, vb.) yaygınlaşması; bilgi-işlem ve iletişimin ağırlık kazanması ile şekillenmektedir. Yeni koşullarda, dar uzmanlaşmanın yerini genel verimlilik artışı hedefi almakta; maliyet avantajı için faktör stokundan ziyade, verimlilik artışına katkıda bulunabilen teknoloji kapasitesi önem kazanmaktadır.

Uluslararası iktisadi etkileşimin kuramsal perspektifinde faktör fiyatları, döviz kuru, verimlilik artışı vb değişkenlerle izaha çalışılan ülkelerin rekabet güçlerinin tespiti için uygulamada bazı uluslararası kuruluşlar tarafından farklı endeksler hesaplanmaktadır. Bu çalışmada, Dünya Ekonomik Forumu (WEF) ve Uluslararas1 Yönetim Geliştirme Enstitüsü (IMD) tarafindan hesaplanan rekabetçilik endeksleri yardımıyla teknolojik gelişme ve rekabet gücü arasındaki ilişkinin tartışılması amaçlanmaktadır.

Üç temel kısım halinde tasarlanan bu çalışmada, teknolojik gelişme ve rekabet gücü olgusu kavramsal çerçevede ele alındıktan sonra teknolojik gelişmenin rekabet gücü üzerindeki etkileri açıklanmakta ve nihayet, WEF ve IMD tarafından hesaplanan endeksler yardımıyla küresel rekabetçilik sıralaması 
değerlendirilmekte; rekabet gücünü artırmaya yönelik politika önerileri paylaşılmaktadır.

\section{TEKNOLOJI VE REKABET GÜCÜ: KAVRAMSAL ÇERÇEVE}

Bu başlık altında, nispi önemine binaen ayrı bir üretim faktörü şeklinde de değerlendirilen ama daha çok emeğin ve sermayenin etkinliğine katkıları yoluyla üretim sürecini şekillendiren bir etken olarak görülen teknoloji ve ilgili kavramlar ile rekabet gücü ve onu belirleyen faktörler açıklanacaktır.

\subsection{Teknoloji}

İktisat literatüründe, girdilerin çıktıya dönüşme yöntemi olarak tanımlanan teknoloji, bilimsel bilginin üretim sürecine aktarılması; bilgi, organizasyon ve tekniklerin bütünü olarak düşünülebilir (Jones, 2007: 73; Smith, 1994: 6). Kavram, geniş anlamıyla, ilk olarak bilimsel bilgi (kodlanmış bilgi), mühendislik bilgisi, know-how veya işletme becerisi (ustalık bilgisi) şeklinde algılanan üretimle ilgili bilgiyi kapsamaktadır. İkinci olarak organizasyonu; örneğin organize edilmiş kamu sektörü faaliyetlerinin ya da bireysel faaliyetlerin bir bütünü olan yönetim ve koordinasyon sistemlerini içermektedir. Üçüncü olarak tekniği; yani makineler, aletler ve diğer donanımlar ile bunların kullanım kurallarını, bakım, onarım ve eğitim gibi yardımcı faaliyetlerini de kapsamaktadır. Teknoloji, aynı zamanda sosyal bir olgudur. Sosyal sistem, teknolojinin gelişmesini ve yayılmasını etkileyen ekonomik ve politik tercihleri meydana getirmektedir. Bu nedenle sosyal değerler, teknolojinin gelişme yolunu biçimlendirmekte; diğer taraftan, teknolojik gelişmeler toplumsal yaşam üzerinde önemli değişimlere sebep olmaktadır.

S1klıkla birlikte kullanılan bilgi ve teknoloji kavramları farklı anlamlar taşımaktadır. İktisadi olarak bilgi, malların üretimi ile arzında ve yeni ürün ve süreçlerin buluş ve tasarımında faydalı bütün bilimsel kanıt ve beşeri uzmanlıkları ifade etmektedir. Kimya ile ilgili bir formülde ya da algoritma hesabındaki gibi kodlanmış (codified) ya da yazılı olmayan bir şeyi nasıl yapacağını bilen bir kişi durumundaki gibi örtük (tacid) olabilen (Greenhalgh, and Rogers, 2010: 6) bilgi, bireyle özdeşse, makine ve bina gibi fiziksel sermayeden ayırt etmek için beşeri sermaye olarak adlandırılmakta; bireyin eğitim ve öğretim yoluyla yeni nitelik ya da bilgi edinimi, onun beşeri sermayesini artırmaktadır. Teknoloji ise, ekonomide mal ve hizmetlerin tasarlanması, yapımı, paketlenmesi ve dağıtımında kullanılan teknikler bütünüdür. $\mathrm{Bu}$ anlamda teknoloji, bilgi stokunun seçilmiş bölümlerinin üretim faaliyetine uygulanmasıdır.

Yeni bir mal ortaya çıkaran veya mevcut malların daha ucuz ve kaliteli biçimde üretimine olanak veren her türlü bilgi, beceri ve süreçleri ifade eden teknoloji, mal üretiminin yanında yönetim, pazarlama vb hizmet ve bilgi konularıyla da ilgilidir (Seyidoğlu, 2007: 664). Teknoloji ya da teknikler bilgisi, 
bir şeyin nasıl üretildiği, nasıl tüketildiği veya kullanıldığına dair, sistematik ve belli bir disiplin çerçevesinde sunulmuş bilgiler demetidir (Türkcan, 2009: 21).

Firma için kullanılabilir olan bütün teknikler seti, dar anlamda firmanın teknolojisini ifade ederken geniş anlamda teknoloji, sadece girdileri bir araya getiren farklı yöntemleri değil, aynı zamanda, organizasyonel süreçleri de kapsar. Endüstri ya da ülke düzeyinde teknoloji, firmaya özgü teknoloji setlerinin bir bileşimidir (Gomulka, 1990: 6). Herhangi bir firma için teknoloji setindeki bir genişleme, endüstride var olan teknolojik bilginin firmalar arası yayılımı vasıtayla gerçekleşir. Ulusal ekonomiler ve dünya ekonomisi için de aynı yorum geçerlidir.

Madde, teknik, güç ve alet ya da makine biçiminde dört bileşeni olan teknoloji, gücü bazı teknikler ve alet ya da makineleri kullanarak herhangi bir maddeyi faydalı bir şekilde değiştirmek amacıyla kullanma sürecidir (Roland, 1992: 83). Ancak teknolojinin statik tanımı için gerekli olsalar da bu bileşenler durağandır; teknolojik değişmeyi açıklamada yetersizdir.

Zaman zaman birbiri yerine kullanılan teknolojik gelişme ve teknolojik değişme kavramları farklı anlamlar taşımaktadır. Teknoloji değiştirmek ya da teknik seçmek, her zaman bir ileri teknolojiye geçmek anlamına gelmemektedir. Teorik olarak üretici, mikro düzeyde sermaye-yoğun bir teknikten emek-yoğun bir tekniğe geçebilir. Ancak makro düzeyde, teknoloji sermaye-yoğun bir çizgide ilerlemekte; mikro düzeyde mümkün olan, makro düzeyde gerçekleşmemektedir. Buna rağmen, makro düzeyde ve tarihsel olarak da, teknolojinin/bilgi stokunun geri dönüş yaptığı, kırıldığı ve yok olduğu da görülmüştür. Ancak günümüz dünyasında, bazı teorik kurgular ve çok kısa süreli/geçici durumlar dışında, emek-yoğun teknoloji tercihi öngörülmemektedir. Artık teknoloji yavaş veya hızlı, ileri doğru bir yönelim içindedir ve her ülke bu eğilime, belli bir tempoda katılmak durumundadır. Bu yaklaşımla teknolojik gelişme, makro düzeyde tek doğrultulu sermaye-yoğun bir süreç; teknolojik değişiklik ise, mikro düzeyde emek-yoğun tercihlerin de yapılabileceği iki ayrı kategori oluşturmaktadır (Türkcan, 2009: 23-24). Bu teorik mülahaza ışığında, bu çalışma için teknolojik gelişme kavramı esas alınacaktır.

Firma/endüstri ya da ülke için ilgili teknoloji setindeki herhangi bir genişleme teknolojik değişme olarak tanımlanır (Gomulka, 1990: 6). Ancak, teknoloji setindeki her artış, teknolojik gelişmeyi göstermez. İlgili girdi ve çıktıların fiyatları ne olursa olsun, etkin olmayan yani aynı girdilerle daha az çıktı üreten ya da aynı çıktıları üretmek için daha fazla girdi gerektiren teknikler seçilmemelidir.

Belirli bir kaynaktan daha fazla veya niteliksel olarak daha yüksek kaliteli çıktı üretmeyi olanaklı hale getiren çeşitli bilgileri ortaya çıkarmak şeklinde tanımlanabilen (Rosenberg, 1982: 3) teknolojik gelişmeye yol açan dört etkenden söz edilebilir (Dosi, 1988: 1125):

i. Ar-ge faaliyetleri,

ii. Teknolojik ilerlemelerin yayınlar, teknik ortaklıklar, gözlem ve öğrenme süreçleri, personel akımları yollarıyla yayılması, 
iii. Yaparak ve kullanarak öğrenme yoluyla elde edilen teknolojik yetenekler*,

iv. Diğer endüstri ya da ülkeler tarafindan geliştirilen ve sermaye ya da ara mallarında içerilmiş olan yeniliğin edinilmesi.

Gelişen teknoloji ile ortaya çıkan teknolojik yeniliğin dört özelliği vardır (Redding, 2002: 1215-1216): Bunlardan ilki, yeniliğin kar arayışındaki iktisadi birimlerin tercihleriyle şekillenmesidir. İkincisi, yeni teknolojilerin keşfi belirsiz bir süreci ifade eder. Üçüncü olarak, teknolojik gelişme, yeniliklerin ve ilaveten ikincil yeniliklerin bileşiminin ürünüdür. Son olarak, bir temel teknoloji için edinilmiş ikincil bilgi, çoğu kez sonraki teknolojinin bilgisiyle sınırlı bir ilişki içindedir.

Teknolojik gelişmeye yol açan etkenlerden teknoloji yayılımı, basitçe teknolojinin bir yerden başka bir yere ya da bir kullanıcıdan başka bir kullanıcıya hareketini ifade eder. Genellikle teknolojik yeniliğin verimlilik artışı üzerindeki iktisadi ve sosyal etkisi sınırlıdır ve sadece yeni teknoloji, üretim süreciyle birleştirildiğinde potansiyel iktisadi faydası artar (Liu, et al, 2010: 6).

Yeniliğin yaygın kullanımın ifade eden teknoloji yayılımı, yeni bir ürünün piyasada satılması örneğindeki gibi yenilikçinin bilinçli çabasıyla olabileceği gibi, yeni bir makinanın diğer firmalar tarafından taklit edilmesi örneğindeki gibi gayri iradi bir şekilde de olabilir. Yenilik, onu gerçekleştirenden ziyade başkaları tarafından ne kadar çok kullanılırsa o kadar fazla yayılır. Taklit, var olan bir yeniliğin doğrudan bir kopyasını yapmayı ya da benzer bir yeni ürün veya sürecin oluşturulmasını amaçlayan faaliyettir. Çoğu durumda, taklitçi, yenilikçi bir firmanın piyasadaki rekabetçisidir (Beije, 1998: 6). Diğer bir ifadeyle taklit, yenilikçi tarafindan geliştirilen bir bilginin diğerleri tarafından kullanımıdır. Taklit ne kadar fazla gerçekleşirse, yenilikçi için karlar, o kadar azalır.

Bilginin kısmi olarak dışlanamaz bir mal olması nedeniyle sınai ar-ge, teknolojik taşmalar yaratabilir. Teknolojik taşmalarla kastedilen, firmaların, bir piyasa işleminde, bilginin başkalarınca bedeli ödenmeksizin kullanımı ve bilgi sahiplerinin mevcut yasalar çerçevesinde etkin korumaya sahip olmamasıdır (Grossman, and Helpman, 1991: 16).

Teknoloji taşması, bilginin, tabiatı gereği bir kamu malı olması nedeniyle, başkalarının ar-ge sonuçlarına, bir iktisadi aktörün daha az ar-ge faaliyetiyle erişebilmesidir (Jaffe, 1986: 984). Teknoloji taşmaları fazla olduğunda, teknolojiyi geliştirenler açısından negatif etkiler daha açı/görülür hale gelmekte; yenilik şevki azalmaktadır. Rekabetin aktörleri olarak firmaların, veri risk düzeyinde yüksek kar hedefleriyle taşma sonuçları çelişmektedir. Ar-ge faaliyetleri maliyetlidir. Firmalar, kendi yöntemleriyle teknolojik yeniliğin toplam maliyetlerini azaltmaya çalışırlar. Karmaşık teknoloji için yüksek yatırım, yüksek risk özellikleri taşır. Buna karşılık teknoloji taşması yatırımcı

*Teknolojik yetenek: Teknolojinin etkin olarak geliştirilmesi, uyarlanması, üretimi, kullanımı ve satın alımını mümkün kılan her türlü nitelik, deneyim ve çabalar bütünüdür (Lall, 2001: 261). 
dışındakilerin ar-ge sonuçlarına düşük maliyetle erişimini mümkün kılar. Taşma beklentisi, maliyetli ar-ge yatırımından kaçınarak aynı zamanda riski azaltmayı seçen işletmelerin teknolojik yenilik sonucu düşük maliyetli rakiplerine karş1 rekabetçi üstünlüğünü azaltır. Bütün karar verici firmaların etkilenmesi nedeniyle nihai sonuç, firmaların bekleme yönünde karar vererek karları toplamasıdır. $\mathrm{Bu}$ teknoloji taşmasının dışsal etkisi, piyasa başarısızlığıyla sonuçlanır ve firmaların yenilik yapma şevkini kırar. Fakat reel iktisadi ortamda, rekabet baskısı ve patent koruma sistemi tarafından oynanan kilit rol nedeniyle çoğu firma, artan teknolojik yenilik şevkine sahiptir ve yenilik faaliyetleri negatif etkiler nedeniyle azalmaz (Liu, et al, 2010: 11-12).

Yeni tekniklerin, makinaların ve üretim süreçlerinin benimsenmesi verimlilik artışının temel bir belirleyicisi olduğu için, bilgi ya da teknolojinin edinimi ve yayılımı, iktisadi gelişme için büyük önem taşımaktadır. Çoğu ar-ge ve yenilik yüksek gelirli ülkeler tarafindan yapılmakta iken, gelişmekte olan ülkeler (GOÜ'ler), yeni üretken bilginin kaynakları olarak büyük oranda ithal teknolojilere bağımlıdır. Bu, GOÜ'lerde, hiç ar-ge yapılmadı̆̆ 1 anlamına gelmemektedir. Yenilik takibi ve adaptasyonunun önemli bir kısmı GOÜ'lerde meydana gelmekte ve global bilgi stokuna katkı sağlamaktadır.

Teknolojinin uluslararası yayılımı, üç ayrı kanalla gerçekleşebilir (Hoekman, and Javorcik, 2006: 1-7). Mal ve hizmet ticareti, bunlardan biridir. Bütün olarak ticaret, teknolojik bilgi aktarımı için potansiyel taşımaktadır. İthal edilen sermaye malları ve teknolojik girdiler, üretim sürecinde kullanılarak doğrudan verimliliği artırabilir. Alternatif olarak, ürün tasarımı ve üretim tekniklerini paylaşan aktörler, yenilikçilere ihracat yaparak teknolojilerini geliştirebilirler. Ticaret, yurtiçi üreticilere, ithal edilen makina ve ekipmanda içerilmiş yeni teknolojilere erişim ya da yurt dışında geliştirilmiş ürünlerin tersine mühendislik firsatları sunarak uluslararası teknoloji yayılımına katkı sağlayabilir; ihracat olanakları, teknolojileri edinme ve geliştirme için teşvikler yaratabilir.

İkinci kanal, doğrudan yabancı yatırım (DYY) ya da projeye özgü arayış içindeki ortak girişimlerdir. DYY'ler, genellikle iştiraklerine teknolojik bilgiyi transfer ederek onların verimliliklerini doğrudan etkilemektedir. Çokuluslu şirketler (ÇUŞ) tarafindan gerçekleştirilen yatırımlar, GOÜ'lere daha verimli/etkin teknolojilere erişim firsatı sağlayabilir. Üretilen bilgi, ortak firmalar ya da işletmelerle sınırlı kalamayacağı için, DYY'ler, çeşitli kanallardan işleyen teknolojik taşmalara yol açabilir (Hoekman, and Javorcik, 2006: 6). Literatürde, gösterim etkileri (demonstration effects), işgücü hareketliliği ve dikey bağlantılar şeklinde DYY kaynaklı üç ayrı teknoloji taşma kanalından söz edilmektedir. Gösterim etkileri, yerli üreticilerin, ÇUŞ'ların ileri teknolojisinden haberdar olmalarının, bu üreticileri kendi üretim yöntemlerini güncellemeye/ geliştirmeye itebileceğini ifade etmektedir. Yeni bir yabancı teknoloji için bedel ödenmesinin oldukça riskli olması nedeniyle, bir ÇUŞ tarafindan bu tür bir teknolojinin yurtiçinde başarıyla uygulanması, belirsizliği azaltmaya yardımcı olarak yerli üreticiler için bilgi taşmaları yaratır. DYY'ler, yerli firmalar tarafından yeni teknolojilerin daha hizlı edinilmesine yol açarak teknoloji edinme maliyetini azaltabilir (Saggi, 2006: 53-59). İkinci taşma kanalı olan işgücü hareketliliği, 
firma içi teknoloji yayılım kanalı olarak doğrudan taklit ve tersine mühendislik şeklindeki diğer kanallardan farklılık arz eder. Çünkü işgücünde içerilmiş bilgi, firmalar arasında işçilerin fiziksel hareketi yoluyla meydana gelir. Ancak, bu kanaldan meydana gelen taşmaların verimlilik sonuçları çok da net değildir. Son olarak, dikey bağlantılar kanalı ile ÇUŞ'lardan, onların tedarikçilerine dikey teknoloji transferi, pozitif dişsallık yaratabilir. Prensip olarak, ÇUŞ’lar, aynı endüstrideki rekabetçilerine bilginin sızmasını önlemek için kritik çalışanlarına yüksek ücret ödeyerek, fikri mülkiyet haklarını güçlendirerek ve anahtar kadro üzerinde rekabet etmeme koşulları koyarak faaliyette bulunduğu sürece, dikey taşmaların ortaya çıkma ihtimali daha yüksektir. Yabancı iştirakler, yerli girdi ve hizmet tedarikçilerinde verimlilik artışlarını özendirerek araştırma maliyetlerini azaltmada bir teşvike sahip oldukları için dikey taşmaların ortaya çıkması daha muhtemeldir. Ancak, geri bağlantılı bir sektöre yabancı firma girişinin, daha fazla aramalı ithalatına sebep olabileceği ya da yabancı girdi tedarikçilerinin girişiyle sonuçlanabileceği düşünüldüğünde, bu mekanizma her zaman ilgili yerli ileri bağlantılı endüstrilerin yararına olmayabilir.

Teknoloji yayılımının üçüncü kanalı, teknoloji satın alımları veya lisanslama yoluyla doğrudan bilgi değiş tokuşudur. Bu, firmalar içinde, ortak girişimler arasında ya da bağlantısız firmalar arasında meydana gelebilir. Lisanslama ve DYY birbiri yerine kullanılabilen fakat tamamlayıcı da olabilen kanallardır. Fikri mülkiyet (telif hakkı) için yapılan uluslararası ödemelerin çoğu, aile şirketleri ve iştirakler arasındaki akımlar olarak firmalar arasında ortaya çıkar. Hangisinin tercih edileceği, fikri mülkiyet haklarının korunma düzeyini etkileyen birçok etkene bağlıdır.

Teknoloji düzeyi/kapasitesi ve gelişim kabiliyeti, her ülke ya da sektörde eş zamanlı ve eşdeğer olmadığından, yeni ürün veya üretim yöntemi, ülkeler ve sektörler arasında transfere konu olmakta; patent/telif hakları ve lisans sözleşmeleri yanında taklit, teknolojinin edinim kanalı olarak işlemekte ve yeni teknolojiler sektör içinde veya sektörler arasında önceden kestirilmeyen yayılma ve taşmalara yol açabilmektedir.

Teknolojik gelişmenin önemli araçlarından biri olan teknoloji transferi, farklı ülke, bölge, sektör, endüstri ya da işletmelerdeki teknolojik gelişmelerin aktarımını sağlamaktadır. Bu yolla, yeni teknoloji bileşimleri ve sistemleri oluşturmaya yönelik üretim süreçleri bir araya getirilmekte; verimlilik ve iktisadi fayda artırılmaktadır. Arz ve talep arasında organize dağıtım faaliyetlerini ifade eden teknoloji transfer sürecinde iki taraf karşılıklı etkileşim içindedir. Teknoloji transferi, teknolojinin üretiminden tam kullanımını sağlayan ve değerini ortaya çıaran uygulamaya aktarımını; teknolojinin bir araya getirilmesi, nakli, iletişimi ve tutundurulmasinı içerir (Liu, et al, 2010: 2-3).

\subsection{Rekabet Gücü}

Bir ülkenin üretim yeteneği ve maliyet avantajının karşılaştırmalı konumunu ifade eden rekabet gücü, ulusal/uluslararası düzeyde, bir ülkenin ürettiği mal ve hizmetlerde katma değerin sürekli ve düzenli artışlar göstererek 
refah düzeyini yükseltmesi; ülke vatandaşlarının yaşam standartlarını iyileştirmesi anlamına gelmektedir (Aktan, 2009). Ancak bu tanımı firma, endüstri, küme ve uluslararası rekabet gücü şeklinde bir ayrıma tabi tutmak da mümkündür. Rekabet gücü, sadece ihracat ve dış ticaret dengesini sağlama yeteneği olarak algılanmamalıdır. Bunun yanı sıra, bir ülkenin gelir ve istihdam düzeyini arttırabilmesi, yaşam kalitesinde kabul edilebilir ve sürekli artışlar sağlayabilmesi ve uluslararası pazar payını arttırabilme yeteneği de ulusal rekabet gücünü gösterir.

Rekabet gücü, farklı ülke/bölge/firmaların yer aldığı uluslararası rekabet ortamında sürdürülebilir iktisadi büyüme için ihtiyaç duyulan yeteneklerin düzeyini yansitır (Cantwell, 2005: 544). Ulusal rekabetçilik, değişen yetenek alanlarını ve dolayısıyla rekabetçi üstünlügü yansıtmak üzere, uluslararası ticaretin zamanla nasıl bir değişim izlediğiyle ilgilidir. $\mathrm{Bu}$, aynı zamanda ülkelerin karşılaştırmalı üstünlüklerinde dönüşüm olarak düşünülebilir.

Ödemeler dengesi sorunlarına yol açmaksızın, ekonomik büyüme ve istihdam artışı başta olmak üzere, bir ülkenin temel iktisadi hedeflerini gerçekleştirme yeteneği olarak algılanabilen (Fagerberg, 1988: 355) uluslararası rekabet gücü için fiyata dayalı ve teknolojiye dayalı rekabet gücü ayrımı da yapılabilir (Aiginger, 1997: 575). Teknolojiye dayalı rekabet gücü, yüksek teknoloji alanlarında rekabet edebilme, yenilik yapabilme ve en gelişmiş piyasa bölümlerinde var olabilme yetkinliği iken fiyata dayalı rekabet gücü, özellikle olgunlaşmış ve homojen piyasalarda/ürünlerde düşük maliyette üretim yeteneğini anlatmaktadır. Fiyat-dışı teknolojik rekabetçilikle, inovasyon ve yeni değer yaratma kanalları/yöntemleri, daha yüksek kalitenin göstergesi/sonucu olarak daha yüksek ortalama fiyatlar üzerinden artan refaha erişilir (Cantwell, 2005: 546).

Uluslararası rekabet, bileşik yapısal güçleri temsil eden ve firmalardan çok ülkelerin yapısal rekabet gücü üzerinde şekillenen, firmalar arası basit rekabetin dışında bir şeydir. Küresel rekabet, firmaların içinde yaşadıkları değişik üretim sistemleri, kurumsal yapılar ve sosyal organizasyonlar arasındaki mücadeleyi temsil etmektedir. Bu rekabette eğitim sistemi, teknolojik altyapı, iş̧̧i-işveren ilişkileri, kamu-özel sektör ilişkileri, iktisat politikaları ve finansal sistem içice geçmiş durumdadır. Uluslararası rekabet ortamında ortaya çıkan gelişmelerle hükümetler giderek önemli bir rol oynamaya başlamışlardır. Nitekim gerek sanayileşmiş ülkelerde gerek sanayileşmekte olan ülkelerin birçoğunda bilim ve teknolojinin önemli bir araç haline geldiği yeni bir yüksek teknoloji neomerkantilizminden söz etmek mümkündür (Ernst, and O'Connor, 1989: 26). Ülke kaynaklarının ve firmalar arası stratejik birleşmelerin yapıldığı, gerek ar-ge çabaları gerek bilgi ve nitelikli insan sermayesi ihtiyaçlarının zamanla daha çok ülkeyi/firmayı içine alarak yayıldığı bir iktisadi ortamda, rekabet artık alışıımışın dışında yeni araçlara dayandırılmaktadır (Yentürk, 1991: 249). 


\subsection{Rekabet Gücünü Belirleyen Faktörler}

Rekabet gücünü belirlemede kullanılan farklı modellerde rekabeti etkileyen faktörler, fiyat ve fiyat-dışı olarak ikiye ayrılmaktadır (Kibritçioğlu, 1996: 4). Fiyat-dış1 faktörlerden biri teknoloji ve ar-ge faaliyetleridir. Rekabet gücü ve ar-ge faaliyetleri birbirini besleyen ögeler olduğu için piyasada rekabet koşulları düzelmeden ar-ge ortamının iyileştirilemeyeceği ve dolayısıyla ar-ge yatırımlarının artırılamayacağı; yatırımlar artırılmadan da rekabet gücünün gelişmeyeceği açıktır (Konya Ticaret Odası, 2006: 1).

Ar-ge faaliyetlerinin ulusal rekabet gücünün yanı sıra firma ve endüstri rekabet gücünün de en önemli belirleyicilerinden biri olduğu, Posner (1961), Keesing (1965) ve Kenen (1965), Vernon (1966), Krugman (1979), Grossman ve Helpman (1989), Porter (1990) vb tarafindan ileri sürülmektedir.

Rekabet gücünün teknolojik gelişme düzeyi ile açıklanabileceğini savunan Posner'e (1961) göre, rekabet üstünlüğünü belirleyen şey, teknolojik yeniliktir. Ülkeler arasındaki karşılaştırmalı maliyet farkı, herhangi bir ülkede teknolojik yeniliğin gerçekleşmesi ile bunun başka bir ülkede taklit edilmesi arasında geçen zaman gecikmesi süresince ticareti mümkün kılar.

Teknolojinin üretimi ve kullanımı üzerinden işgücünün niteliği, rekabet gücü açısından önem arz etmektedir. Keesing (1965) ve Kenen (1965), dış ticaretin nedenini, işgücü nitelik farklılıklarına bağlamışlardır. Bu yaklaşıma göre, belirli türlerdeki mesleki ve nitelikli işgücü bakımından zengin ülkeler, üretimi büyük ölçüde bu faktörlere bağlı olan mallarda rekabet avantajına ve ihracat kabiliyetine sahip olacaktır.

Teknoloji açığı teorisinin dinamik versiyonu (Meliciani, 2001: 34) olarak Vernon (1966) tarafindan geliştirilen Ürün Dönemleri Teorisi'ne göre, üretilen her mal veya hizmet, piyasaya sürüldükten sonra üç aşamadan geçer. Bunlar, giriş, büyüme, olgunluk dönemleridir. Bir mal bu aşamaları geçerek yeni bir mal durumundan eski bir mal durumuna gelirken, üretimin coğrafi yeri de değişime uğrar.

Krugman (1979), Vernon'un Ürün Dönemleri Teorisi'ni basit bir genel denge modeli çerçevesinde ele almıştır. Modelde yenilikçi Kuzey ve yenilikçi olmayan Güney şeklinde iki ülke grubu yer almaktadır. Yenilik yeni bir ürünün geliştirilmesi şeklinde olmaktadır. Bu yeni ürünler ilk olarak Kuzey'de üretilebilir. Fakat zamanla üretim teknolojisi Güney için de kullanılabilir hale gelir. Bu teknolojik gecikme, Kuzey'in yeni ürünleri ihraç ederken eski ürünleri ithal ettiği ticaret biçimini ortaya çıkarır. Kuzey'in kişi başına geliri yeni ürünlere ilişkin monopol gücünden kaynaklanan rant benzerine bağlıdır. Böylece Kuzey, sadece Güney'e karşı görece pozisyonunu sürdürmek için değil, aynı zamanda mutlak olarak reel gelirini belirli bir düzeyde korumak için de sürekli olarak yenilik yapmak zorundadır.

Sınai yeniliği, uzun dönem iktisadi büyümenin itici gücü olarak ele alan Grossman ve Helpman (1991: 18-21), teknolojik gelişmenin kar maksimizasyonu amaçlı iktisadi birimlerin yaptığı yatırımlardan kaynaklandığını ileri sürmektedir. 
Firmalar, yeni mallar geliştirmek için ar-ge yapmaktadır. Yeni mal üreticileri arge harcamalarının ödülü olarak tekelci karlar elde etmektedir. Gelişmiş ürün üreticileri, daha düşük nitelikli mal üretenlerle rekabette üstünlük sağlamaktadır. Böylece yenilik, nihai mal üreten sektörlerde toplam faktör verimliliğini artırmakta ve büyüme nihai çıktı miktarında standart bir artış biçimini almaktadır. Modelde, fiziksel sermaye birikiminin de dikkate alınmasıyla, geleneksel büyüme teorileri ve bilgi birikimine dayalı yaklaşımın bir sentezi yapılmaktadır. Büyümenin uzun dönemde yenilik güçleri tarafından harekete geçirilmesi, bina ve makinelerin verimliliğini artırarak sermaye yatırımları için teşvikler sunmaktadır. Açık ekonomi koşullarında, ticaret ve teknoloji politikalarının yenilik ve büyüme üzerindeki etkileri bağlamında, bir ülkedeki yenilik, yüksek teknoloji sektörlerinde (içsel) karşılaştırmalı üstünlük yaratmaktadır. Teknolojik taşmaların coğrafi olarak toplanması durumunda, ülke büyüklüğü ve önceki arge deneyimi, ülkenin ticaret yapısının belirlenmesi konusunda etkili olmaktadır. Uluslararası iktisadi bütünleşme düzeyi ve hükümet (ticaret, teknoloji, sanayi) politikaları, ticaret ortaklarındaki büyüme sürecini etkilemektedir. Ayrıca, sanayileşmiş Kuzey ve gelişmekte olan Güney'deki öğrenme süreçleri arasında karşı1lklı bağımlılık söz konusudur ve Güney'de öğrenme, daha önce Kuzey tarafından geliştirilen teknolojilerin taklit edilmesi biçiminde olmaktadır.

Porter'a (1990: 71) göre, bir ülkenin belirli bir endüstrideki rekabetçi üstünlüğünü belirleyen dört temel etken vardır:

i. Faktör koşulları: Belirli bir endüstride rekabet edebilmek için gerekli olan, nitelikli işgücü gibi üretim faktörleri yanında altyapı açısından ülkenin durumu.

ii. Talep koşulları: Ülkenin bir endüstride üretilen ürünler veya hizmetler için yurtiçi talep yapısı.

iii. İlgili veya destekleyici endüstriler: Uluslararası düzeyde rekabet gücü olan tedarikçi ve yan endüstrilerin ülkede mevcudiyeti.

iv. Firma stratejisi, yapısı ve rekabet düzeyi: Yurtiçi rekabetin yapısı, ülkedeki şirketlerin nasıl kurulduğu, organize edildiği ve yönetildiğine ilişkin ülke koşulları.

Ulusal "elmas" olarak anılan rekabetçi üstünlüğün bu belirleyicileri birbirini etkilemektedir. Örneğin talep koşullarındaki elverişlilik, ilgili endüstrideki rekabet durumu, firmaların bu koşullara yanıt vermesini mümkün kılacak yeterlilikte değilse, rekabetçi üstünlüğe yol açmayacaktır (Porter, 1990: 72). Öte yandan, bir belirleyicideki gelişme, diğerlerinde de iyileşme yaratabilir.

Ulusal rekabetçi üstünlük açısından etkili unsurlardan ilki olan ülkedeki faktör koşulları, temel ve gelişmiş faktörler biçiminde iki grupta ele alınmaktadır. Temel faktörler, doğal kaynaklar, iklim şartları ve coğrafi konum ile niteliksiz ve yarı-nitelikli işgücü ve sermaye gibi hususları içerirken gelişmiş faktörler daha ziyade modern iletişim altyapısı, öncelik arz eden mesleklerde yüksek düzeyde eğitimli işgücü ve sofistike disiplinlerde üniversite araştırma enstitüleri, vb kapsamaktadır. Geliştirilmeleri, gerek fiziki gerekse beşeri alanlarda büyük boyutlarda ve sürekli bir yatırımı gerektirdiğinden, temel faktörlere göre daha kıt ve elde edilmeleri güç olan gelişmiş faktörler, rekabetçi üstünlük açısından kritik 
önem arz etmektedir. Bunlara sahiplik, farklılaştırılmış veya özgün ürünler ve tescilli üretim teknolojileri gibi ileri derecede rekabetçi üstünlük için elzem görülmektedir. Üretim faktörleri arasındaki ikinci ve benzer bir ayırım, genel ve özel olmak üzere, niteliklerine göre yapılmaktadır. Genel faktörler, endüstrilerin çoğunda yaygın olarak kullanılan, karayolu, demiryolu vb genel ulaştırma altyapısı yanında işgücü arzı ve sermayeyi ifade ederken, özel faktörler belirli bir özellik arz eden altyapı, belirli alanda nitelikli işgücü, bilgi birikimi ve daha spesifik alanlara veya belirgin bir endüstriye özgü diğer faktörlerdir (Porter, 1990: 79). Genel faktörler, çoğu ülkede genellikle mevcut ve eksikliğinin giderilmesi daha kolay olduğundan özel faktörler, genel faktörlere göre, rekabetçi üstünlük açısından daha kesin ve sürdürülebilir bir temel oluşturmaktadır.

Ülkeler geliştikçe, rekabetçi üstünlükleri ve rekabet etme tarzları bakımından iyileşme gösterirler. Porter (1990: 545-556), ülkeleri rekabetçi gelişme aşamaları açısından faktör etken, yatırım etken, inovasyon etken ve servet (refah) etken olarak dört gruba ayırmaktadır. Özellikle, inovasyon etken aşamada, ileri teknoloji ile ürün ve hizmet üretebilme yeteneği, rekabetçi üstünlüğün temel kaynağı olarak görülmektedir.

\section{REKABET ÜSTÜNLÜĞÜNÜN KAYNAĞI OLARAK TEKNOLOJIKK GELIŞME}

Genel olarak, teknoloji geliştirme yeteneğinin daha iyi büyüme performansı sağlaması ve uluslararası rekabetçiliği artırması beklenir. Teknolojik açıdan durgun faaliyetlerden ziyade hızlı ürün ve süreç yeniliklerine sahip faaliyetler, hızla artan bir talep yapısı oluştururlar. Dünya ticaretinde yer alan en dinamik ürünler, karmaşık ve hızla değişen teknolojileri içermektedir. Ölçek, nitelik ve teknoloji gereksinimleri açısından zayıf olan düşük teknolojili faaliyetlerle karşılaştırıldığında, teknoloji yoğun faaliyetler rakiplerin piyasaya girişine karşı daha az saldırıya açıktır. Diğer koşullar sabitken, teknoloji yoğun faaliyetler hem bazı yeteneklerin daha hızlı gelişmesine katkıda bulunmakta hem de bu yeteneklerin niteliğinin yükselmesine yol açmaktadır. Bu tür faaliyetler bilimin teknolojiye sürekli uygulanabilmesi için gereken yüksek firsatlar ve öğrenme potansiyellerine sahiptir. Teknoloji yoğun faaliyetlerdeki yetenekler, teknoloji ve piyasa eğilimlerine daha uyarlanabilir niteliktedir ve böylece değişen rekabet koşullarına daha esnek biçimde karşılık verebilmekte; ulusal teknolojik sisteme ve diğer faaliyetlere daha geniş dışsallıklar sunmaktadır (Lall, 2000: 7 $8)$.

Geleceğin teknolojilerini tasarlayan, teknoloji stratejisini oluşturan, ar-ge yapan ve teknoloji geliştirmeye önem veren ülke ve işletmeler uluslararası piyasalarda rekabet avantajı sağlamaktadır. Teknolojik yenilik ile uluslararası rekabetçilik arasında üç ayrı bağlantı vardır. İlk olarak süreç yenilikleri, üretim/çıktı maliyetlerini azaltarak rekabetçiliği artırır. İkinci olarak, ikincil ürün yenilikleri malların kalitesini artırarak onları hem yurtiçi hem de yurt dışı piyasalarda daha cazip hale getirir. Üçüncüsü, ürün yenilikleri, sınırlı süre için bu ürünlerin piyasada tutunmasına yardımcı olacak bir monopolistik durum 
yaratarak monopol karı kazandırır (Archibugi, and Michie, 1998: 10-11). Teknolojik yeniliğin yenilikçi ülkeye sağlayacağı faydalar, kısa dönemde ithalat ihtiyacını ve döviz harcamalarını azaltarak dış ticaret dengesini olumlu etkilerken, uzun dönemde, dış ticaret hadlerinde iyileşme ve yüksek getiri sağlayan sektörlerde uzmanlaşma yeteneği olarak karşımıza çıkmaktadır.

\section{REKABET GÜCÜNÜN ÖLÇÜLMESİ}

Rekabet gücünün ölçülmesine yönelik farklı yaklaşımlardan ilki ve en sık kullanılanı, Liesner'in (1958) önerdiği ve daha sonra Balassa (1965) tarafindan işlevsel hale getirilen ve sektörün/ülkenin diş ticaret performansını izah eden Açıklanmış Karşılaştırmalı Üstünlük (AKÜ) Endeksi'dir. Nispi İhracat Avantajı Endeksi, Nispi İthalat Nüfuz Endeksi, Endüstri-içi Ticaret Endeksi, İhracatta Uzmanlaşma Endeksi, İhracatta Benzerlik Endeksi vb endeksler de rekabet gücünün ölçülmesinde kullanılmaktadır. Ayrıca birim emek maliyeti, pazar payı, döviz kuru gibi değişkenlerin yanı sıra bunların bir bileşimi olan ve kurumsal unsurları da içeren çeşitli rekabet gücü göstergeleri ve formel ölçütler oluşturulabilmektedir. Küresel rekabet gücünü kendi oluşturdukları yöntemlere göre ve endeksler biçiminde hesaplayıp sonuçları raporlar halinde dönemsel olarak yayınlayan farklı kurumlar bulunmaktadır. Çalışmamızın bu kısmında, Dünya Ekonomik Forumu (WEF) ve Uluslararası Yönetim Geliştirme Enstitüsü'nün (IMD) uluslararası rekabet gücü kavramına bakışları, rekabet gücünü ölçüm yöntemleri ile kriterleri üzerinde durulduktan sonra bu kurumlar tarafindan hesaplanan güncel rekabet gücü endekslerine göre ülkelerin rekabetçilik sırlamalarındaki konumları ve teknolojik gelişmenin buna katkısı incelenecektir.

\subsection{Dünya Ekonomik Forumu ve Küresel Rekabetçilik Endeksi}

Dünya Ekonomik Forumu (World Economic Forum-WEF), 1979'dan itibaren her yıl Küresel Rekabetçilik Raporu (Global Competitiveness ReportGCR) yayınlamaktadır. 2005 yılından sonra güncellenen bu raporda, ülkelerin verimlilik düzeylerini belirleyen faktörler, politikalar ve kurumlar bütünü olarak tanımlanan rekabetçilik, Küresel Rekabetçilik Endeksi (KRE; Global Competitiveness Index-GCI) ile ölçülmektedir (WEF, 2014: 4). KRE, çok sayıda parametreyi dikkate alarak ülkeler arasında bir sıralama yapmay1 önermekte; ülkelerin uluslararası rekabet düzeyinin makro ve mikro bileşenlerine ilişkin kapsamlı bir değerlendirme sunmaktadır.

Küresel rekabet gücünü etkileyen çok sayıda bileşenin ağırlıklı ortalaması alınarak hesaplan KRE'deki her bir bileşen, rekabetçiliğin farklı bir boyutunu yansitmaktadır. Tablo-1, 144 ülkeyi kapsayan 2014-2015 Raporu'ndaki KRE bileşenleri ve ağılıklarını göstermektedir. Bu bileşenler ayrı ayrı sunulmakla birlikte birbirlerinden tamamen bağımsız olarak değerlendirilmemelidir: birbirleriyle yakın etkileşim ve birbirlerini güçlendirme eğilimindedirler; bir alandaki eksiklik genellikle diğerleri üzerinde olumsuz etkiye yol açar (WEF, 
2014: 8-9). Örneğin, güçlü bir yenilik kapasitesinin (12. Bileşen), yeni teknolojileri özümseme (9. Bileşen) becerisine sahip, sağllklı, iyi eğitimli ve yetişmiş işgücü (4. ve 5. Bileşen) ile ar-ge için yeterli finansman (8. Bileșen) ya da yenilikleri piyasaya çekmeyi mümkün hale getiren mal piyasaları (6. Bileşen) olmadan başarılması oldukça zordur.

Yenilik, ülkeler için özellikle bilginin sınırlarına yaklaştıkça önemli hale gelmektedir ve dışarıda üretilmiş teknolojileri sadece benimseyerek ve entegre ederek daha fazla değer yaratma imkanı kaybolma eğilimindendir. GOÜ'ler, mevcut teknolojileri edinerek ya da diğer alanlarda artımsal iyileştirmeler yaparak verimliliklerini hala geliştirebilmelerine rağmen, kalkınmanın yenilik aşamasına ulaştıklarında, bu durum artık verimliliği artırmak için yeterli değildir. $\mathrm{Bu}$ ülkelerdeki firmalar, rekabetçi üstünlüğü sürdürmek için ileri teknoloji ürün ve süreçlerini tasarlamak ve geliştirmek, yüksek katma değerli faaliyetlere yönelmek zorundadırlar. Bu ilerleme, yenilikçi faaliyete olanak sağlayan ve hem kamu hem de özel sektör tarafindan desteklenen bir ortamı gerekli kılmaktadır. $\mathrm{Bu}$ bilhassa, özel sektör tarafindan yeterli ar-ge yatırımı; yeni teknolojileri geliştirmek için ihtiyaç duyulan temel bilgiyi yaratabilecek yüksek nitelikli araştırma kurumlarının varlı̆̆ı; ar-ge konusunda üniversite ve sanayi arasında kapsamlı işbirliği, endeksin diğer bileşenlerinde analiz edilen risk sermayesi ve finansmana erişim ve yüksek rekabetçilik düzeylerine ilave olarak mülkiyet haklarının korunması anlamına gelir.

KRE'de özellikle teknolojik altyapı ilintili bileșeni ele alacak olursak, bu etken, bir ekonominin tüm endüstrilerinin üretkenliğini artırabilmek için var olan teknolojileri hayata geçirmedeki becerisini ölçmektedir. Bu anlamda, ülkenin rekabetçilik için yenilik yaratma ve etkinliğin artırılmasında günlük faaliyet ve üretim süreçlerinde, bilişim teknolojilerini bütünüyle geliştirme kapasitesi üzerinde özellikle durulmalıdır. Diğer iktisadi sektörlere yönelik önemli taşmaları ve endüstri genelinde altyapı oluşturmadaki rolü dikkate alındığında bilişim teknolojileri, genel amaçlı teknolojilere dönüşmüş durumdadır. Artık bilişim teknolojilerine ulaşılabilirlik ve bu teknolojilerin kullanımı, ülkenin genel teknolojik altyapısının temel göstergesidir. Bu bağlamda, bir teknolojinin ülke sınırları içinde veya dışında geliştirilmiş olmasının, o ülkenin verimliliğini artırma kabiliyetiyle ilgisi yoktur (WEF, 2014: 7-8). Ana nokta, ülkede faaliyette bulunan firmaların teknolojik olarak gelişmiş ürünlere ve onları kullanma ve içselleştirme yeterliliğine erişebilmesidir.

KRE, kişi başına GSYİH ve toplam ihracat içinde mineral ürünlerinin payını dikkate alarak kalkınma aşamaları açısından ülkeleri üçe ayırmaktadır (WEF, 2014: 9-10): faktör odaklı, verimlilik/etkinlik odaklı ve yenilik odaklı ülkeler. "Faktör Odaklı Ekonomiler", esasen nitelikli olmayan işgücü ve doğal kaynaklar şeklinde betimlenen faktör donatımlarına göre rekabet eder; bu ülkelerdeki işletmeler, düşük verimlilik ve ücret düzeyleriyle fiyat temelinde rekabet ederken temel ürün ve malların satışını gerçekleştirirler. Rekabet gücünü korumak/artırmak, öncelikle istikrarlı makroekonomik ortam, iyi işleyen kamu ve özel sektör kurumları, iyi bir altyapı ve en az temel eğitim almış sağlıklı bir işgücüne bağlıdır. Bu unsurlar, Tablo-1'de yer alan “temel gereklilikler”dir. 
Tablo 1: Küresel Rekabetçilik Endeksinin Yapısı ve Hesaplanış1

\begin{tabular}{|c|c|c|c|c|}
\hline & Küresel Rekabet Gücü Endeksi Bileșenleri & İlgili Kate & ideki & $1 \%)$ \\
\hline \multirow{17}{*}{ 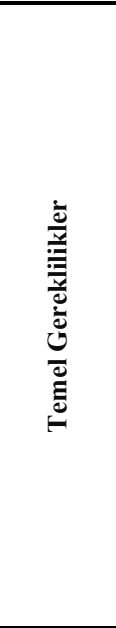 } & 1. KURUMLAR & & & 25 \\
\hline & 1.A. Kamu Kurumları & & 75 & \\
\hline & 1A.1. Mülkiyet Hakları & 20 & & \\
\hline & 1A.2. Ahlaki Değerler Ve Yolsuzluk & 20 & & \\
\hline & 1A.3. Haksız Biçimde Yaratılan Etki-Kayırmacılık & 20 & & \\
\hline & 1A.4. Kamu İdaresinin Verimli Çalışmaması & 20 & & \\
\hline & 1A.5. Güvenlik & 20 & & \\
\hline & 1.B. Özel Sektör Kuruluşları & & 25 & \\
\hline & 1.B.1. Kurumsal Ahlaki Değerler-Etik & 50 & & \\
\hline & 1.B.2. Hesap Verebilirlik & 50 & & \\
\hline & 2. ALT YAPI & & & 25 \\
\hline & 2.A.Ulaştırma Altyapısı & & 50 & \\
\hline & 2.B. Elektrik ve Telefon Altyapısı & & 50 & \\
\hline & 3. MAKROEKONOMİK ORTAM & & & 25 \\
\hline & 4. SAĞLIK VE TEMEL EĞITTIM & & & 25 \\
\hline & 4.A. Sağlık & & 50 & \\
\hline & 4.B. İlköğretim & & 50 & \\
\hline \multirow{21}{*}{ 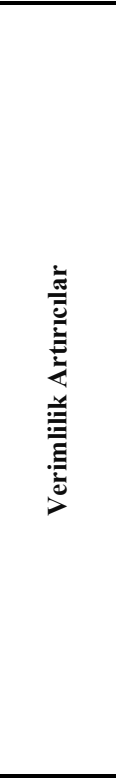 } & 5. YÜKSEK ÖĞRETIMM VE EĞİTİM & & & 17 \\
\hline & 5.A. Eğitimin Niceliği & & 33 & \\
\hline & 5.B. Eğitimin Niteliği & & 33 & \\
\hline & 5.C. İşbaşında Eğitim & & 33 & \\
\hline & 6. ÜRÜN PIYASALARININ ETKINLIĞĠ & & & 17 \\
\hline & 6.A. Rekabet & & 67 & \\
\hline & 6.A.1. İç Rekabet & Değişken & & \\
\hline & 6.A.2. Dış Rekabet & Değişken & & \\
\hline & 6.B. Talep Koşullarının Niteliği & & 33 & \\
\hline & 7. EMEK PIYYASALARININ ETKİNLIĞİ & & & 17 \\
\hline & 7.A. Esneklik & & 50 & \\
\hline & 7.B. İşgücü Kabiliyetinin Etkin Kullanımı & & 50 & \\
\hline & 8. FINANS PIYYASALARININ GELIŞSISŞLIĞİ & & & 17 \\
\hline & 8.A. Etkinlik & & 50 & \\
\hline & 8.B. Güvenilirlik & & 50 & \\
\hline & 9. TEKNOLOJİK ALTYAPI & & & 17 \\
\hline & 9.A. Teknolojiyi Benimseyebilme & & 50 & \\
\hline & 9.B. Bilişim Teknolojilerinin Kullanımı & & 50 & \\
\hline & 10. PAZAR BÜYÜKLÜĞÜ & & & 17 \\
\hline & 10.A. İç Pazarın Büyüklüğü & & 75 & \\
\hline & 10.B. Diş Pazarın Büyüklüğü & & 25 & \\
\hline \multirow{2}{*}{ 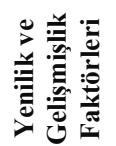 } & 11. İŞ DÜNYASININ GELIŞMISŞLIKK DÜZEYİ & & & 50 \\
\hline & 12.YENILİK & & & 50 \\
\hline
\end{tabular}

Kaynak: WEF, 2014: 49-51

Bir ülke daha rekabetçi hale geldikçe, verimlilik odaklı kalkınma aşamasına geçilecektir. Bu aşamada ürün kalitesi de artarken rekabetçilik, yüksek eğitim ve mesleki eğitim, etkin işleyen işgücü piyasaları, gelişmiş finansal piyasalar, mevcut teknolojilerden yararlanabilme yeteneği ve geniş bir iç ve dış piyasa ile sağlanmaktadır. Bu unsurlar Tablo-1'de "verimlilik artırıcılar" olarak gösterilmekte ve kalkınmanın bu aşamasında bulunan ülkeler, "Verimlilik Odaklı Ekonomiler" olarak adlandırılmaktadır. Nihayet, ülkeler yenilik odaklı kalkınma 
aşamasına geçtiğinde, ücretlerdeki yükselmenin de etkisiyle işletmeler yeni ürünlerle rekabet edebilirlerse, ulaşllan yüksek ücret düzeylerini ve yaşam standardını sürdürülebileceklerdir. Bu aşamaya ulaşan ülkelerdeki işletmeler, en gelişmiş üretim süreçlerinin kullanıldığı yeni ve faklı ürünleri üreterek ve yenilik yaparak rekabet eder; "Yenilik Odaklı Ekonomiler" olarak nitelenir (WEF, 2014: 9-10).

KRE, kalkınma aşamalarını, ülkenin bulunduğu düzeye göre bileşenlere daha yüksek nispi ağırlık vererek dikkate alır. $\mathrm{Bu}$ durumda, 12 bileşenin tamamının bütün ülkeler için belirli düzeyde önemli olmasına rağmen, her bir bileşenin nispi ağırlığı, ülkenin bulunduğu kalkınma aşamasına göre değişmektedir. Bileşenler, her biri bir kalkınma aşaması için kritik olan üç altendekse ayrılır* (WEF, 2014: 9-10). Temel gereklilikler alt-endeksi, faktör odaklı ülkeler; etkinlik artırıcılar alt-endeksi, etkinlik odaklı ülkeler; yenilik ve gelişmişlik faktörleri alt-endeksi ise, yenilik odaklı ülkeler için kritik olan bileşenleri kapsar.

\subsection{Uluslararası Yönetim Geliştirme Enstitüsü ve Rekabet Gücü Ölçümü}

Uluslararası Yönetim Geliştirme Enstitüsü (International Institute for Management Development - IMD), her yıl Dünya Rekabetçilik Yıllığı (World Competitiveness Yearbook) ile ülkeleri rekabet güçlerine göre siralarken, ekonomik yapı, siyasi yapı, altyapı, vb çok sayıda gösterge kullanmaktadır.

Rekabetçiliği teşvik edecek etkin yapı, kurum ve politikalara sahip ortamın önemini vurgulayan (IMD, 2014: 480) ve 1989'dan itibaren yayınlanan Dünya Rekabetçilik Y1llığı, şirketlerin rekabet gücünün sürdürülebilmesi için gerekli ortamın oluşturulması ve idamesi bağlamında, ülkelerin yeteneğini sinıflandırmakta ve analiz etmektedir. Dünya Rekabetçilik Yıllığı'nda yer verilen ve Tablo-2'de yansitılan dört temel rekabetçilik faktöründen her biri, beş altfaktöre ayrılmakta ve her alt-faktörde rekabet gücünün ayrı bir yönü ortaya konmaktadır.

2014 Dünya Rekabetçilik Yıllığı, 338 rekabetçilik kriteri kullanmaktadır (IMD, 2014: 480-484). İlk aşamada her ekonominin performans1, standart dağılım metoduyla her bir kriter için değerlendirilmekte; sonra ekonomiler 253 kritere dayalı olarak sinıflandırılmaktadır. Kriterlerin hesaplanmasında, 135 'i uluslararası, bölgesel ya da ulusal kaynaklardan; 118'i ise, uluslararası panel ve yönetici anketlerinden sağlanan verilerden yararlanılmaktadır. Ayrıca 85 kriter, yalnızca geçmişle ilgili bilgi vermekte ve sınıflandırmanın belirlenmesinde kullanılmamaktadır. Teknolojik ve Bilimsel altyapı başlıkları altında 23'er kriter bulunmakta; burada daha çok ülkelerin yenilik kapasitelerinin ölçülmesine yönelik göstergeler yer almaktadır (IMD, 2014: 408-409). Bunlardan bazıları,

\footnotetext{
* Bu çalışmada, kalkınmanın farklı aşamasında olan ülkeler için temel gereklilik, verimlilik artırıcılar ile yenilik ve gelişmişlik bileşenlerinin ağırlı̆ğ sırasıyla, faktör odaklı ekonomilerde $\% 60, \% 35$ ve $\% 5$; etkinlik odakl ekonomilerde $\% 40, \% 50$ ve $\% 10$ iken yenilik odaklı ekonomilerde $\% 20, \% 50$ ve $\% 30$ 'dur.
} 
telekomünikasyon yatırımı, sabit ve mobil telefon abone sayıs1, kullanımdaki bilgisayar, internet kullanıcı sayısı, yüksek teknoloji ihracı, özel kesim ve kamu kesimi ar-ge harcamaları, ar-ge personeli, bilimsel makaleler, patent başvuruları, araştırmacı ve bilim adamı sayıları, üniversite ve sanayi arasındaki teknoloji transferi, fikri mülkiyet hakları ve yenilik kapasitesidir.

Tablo-2: IMD Rekabetçilik Faktörleri ve Kriterleri

\begin{tabular}{|c|c|c|}
\hline Faktörler & Açıklama & Alt Faktörler \\
\hline $\begin{array}{l}\text { Ekonomik Performans ( } 83 \\
\text { Kriter) }\end{array}$ & $\begin{array}{l}\text { Yurtiçi ekonominin makroekonomik } \\
\text { değerlendirmesi yapılmaktadır. }\end{array}$ & $\begin{array}{l}\text { Yurtiçi Ekonomi } \\
\text { Uluslararası Ticaret } \\
\text { Uluslararası Yatırım } \\
\text { İstihdam } \\
\text { Fiyatlar } \\
\end{array}$ \\
\hline Kamu Etkinliği (70 kriter) & $\begin{array}{l}\text { Rekabet gücüne katk1 sağlayacak } \\
\text { hükümet politikalarının genişletilmesidir. }\end{array}$ & \begin{tabular}{|l|} 
Kamu Maliyesi \\
Maliye Politikası \\
Kurumsal Çerçeve \\
İş Kanunu \\
Sosyal Çerçeve \\
\end{tabular} \\
\hline İş Etkinliği (71 kriter) & $\begin{array}{l}\text { Yenilikçi, karlı, sorumlu davranışlar } \\
\text { gerçekleştiren işletmeleri teşvik edecek } \\
\text { ulusal çerçeveyi oluşturmaktadır. }\end{array}$ & $\begin{array}{l}\text { Verimlilik ve Etkinlik } \\
\text { İşgücü Piyasası } \\
\text { Finans } \\
\text { Yönetim } \\
\text { Uygulamaları } \\
\text { Davranış ve Değerler } \\
\end{array}$ \\
\hline Altyap1 (114 Kriter) & $\begin{array}{l}\text { İş dünyasının ihtiyaç duyduğu temel, } \\
\text { teknolojik, bilimsel ve beşeri kaynaklara } \\
\text { ilişkin altyapıyı oluşturmaktadır. }\end{array}$ & $\begin{array}{l}\text { Temel Altyap1 } \\
\text { Teknolojik Altyapı } \\
\text { Bilimsel Altyap1 } \\
\text { Sağlık ve Çevre } \\
\text { Eğitim } \\
\end{array}$ \\
\hline
\end{tabular}

Kaynak: IMD, 2014: 480-481.

\subsection{Uluslararası Endekslere Göre Rekabet Gücü Sıralaması}

2013-2014 ve 2014-2015 KRE’ye göre ülkelerin rekabetçilik sıralamalarının yansıtıldığı Tablo-3'te de görüldüğü üzere, İsviçre, Singapur, ABD, Finlandiya ve Almanya ilk beş sırada yer almış; ABD, 2013 yılında 5. sırada iken 2014 yılında 3. sıraya yükselmiştir. Türkiye, 4,46 skoru ile bir önceki yıla göre 1 sıra gerileyerek 45. sıraya düşmüş; rekabet gücü azalmıştır. Sıralamada dikkat çekici bir şekilde yükselen, diğer ülkeler karşısında rekabet gücünü artıran ülkeler, Portekiz, Rusya Federasyonu, Çek Cumhuriyeti, Birleşik Arap Emirlikleri, Morityus, Letonya, Filipinler, Tayland ve Malezya olurken gerileyen ülkeler, İsveç, Avusturya, Suudi Arabistan ve Kuveyt'dir. 
Tablo-3: Dünya Ekonomik Forumu Küresel Rekabetçilik Endeksi

\begin{tabular}{|c|c|c|c|c|c|c|c|}
\hline \multirow{2}{*}{ Ülke veya Ekonomi } & \multirow{2}{*}{$\begin{array}{c}\begin{array}{c}2014-2015 \\
\text { Skor* }\end{array} \\
(1-7)\end{array}$} & \multicolumn{2}{|c|}{ Siralama* } & \multirow{2}{*}{$\begin{array}{l}\text { Ülke veya } \\
\text { Ekonomi }\end{array}$} & \multirow{2}{*}{\begin{tabular}{|c|}
$\begin{array}{c}2014-2015 \\
\text { Skor* }\end{array}$ \\
$2014-2015$
\end{tabular}} & \multicolumn{2}{|c|}{ Siralama* } \\
\hline & & 2014-2015 & 2013-2014 & & & 2014-2015 & 2013-2014 \\
\hline İsviçre & 5.7 & 1 & 1 & Estonya & 4.71 & 29 & 32 \\
\hline Singapur & 5.65 & 2 & 2 & İzlanda & 4.71 & 30 & 31 \\
\hline $\mathrm{ABD}$ & 5.54 & 3 & 5 & Tayland & 4.66 & 31 & 37 \\
\hline Finlandiya & 5.5 & 4 & 3 & Porto Riko & 4.64 & 32 & 30 \\
\hline Almanya & 5.49 & 5 & 4 & Şili & 4.6 & 33 & 34 \\
\hline Japonya & 5.47 & 6 & 9 & Endonezya & 4.57 & 34 & 38 \\
\hline Hon Kong & 5.46 & 7 & 7 & İspanya & 4.55 & 35 & 35 \\
\hline Hollanda & 5.45 & 8 & 8 & Portekiz & 4.54 & 36 & 51 \\
\hline İngiltere & 5.41 & 9 & 10 & Çek Cumh. & 4.53 & 37 & 46 \\
\hline İsveç & 5.41 & 10 & 6 & Azerbaycan & 4.53 & 38 & 39 \\
\hline Norveç & 5.35 & 11 & 11 & Morityus & 4.52 & 39 & 45 \\
\hline Birleşik Ar.Em. & 5.33 & 12 & 19 & Kuveyt & 4.51 & 40 & 36 \\
\hline Danimarka & 5.29 & 13 & 15 & Litvanya & 4.51 & 41 & 48 \\
\hline Tayvan, Çin & 5.25 & 14 & 12 & Letonya & 4.5 & 42 & 52 \\
\hline Kanada & 5.24 & 14 & 14 & Polonya & 4.48 & 43 & 42 \\
\hline Katar & 5.24 & 16 & 13 & Bahreyn & 4.48 & 44 & 43 \\
\hline Yeni Zelanda & 5.2 & 17 & 18 & Türkiye & 4.46 & 45 & 44 \\
\hline Belçika & 5.18 & 18 & 17 & Oman & 4.46 & 46 & 33 \\
\hline Lüksemburg & 5.17 & 19 & 22 & Malta & 4.45 & 47 & 41 \\
\hline Malezya & 5.16 & 20 & 24 & Panama & 4.43 & 48 & 40 \\
\hline Avusturya & 5.16 & 21 & 16 & Italya & 4.42 & 49 & 49 \\
\hline Avusturalya & 5.08 & 22 & 21 & Kazakistan & 4.42 & 50 & 50 \\
\hline Fransa & 5.08 & 23 & 23 & Kosta Rika & 4.42 & 51 & 54 \\
\hline Suudi Arabistan & 5.06 & 24 & 20 & Filipinler & 4.4 & 52 & 59 \\
\hline İrlanda & 4.98 & 25 & 28 & Rusya Fed. & 4.37 & 53 & 64 \\
\hline G. Kore & 4.96 & 26 & 25 & Bulgaristan & 4.37 & 54 & 57 \\
\hline İsrail & 4.95 & 27 & 27 & Barbados & 4.36 & 55 & 47 \\
\hline Çin & 4.89 & 28 & 29 & $\begin{array}{l}\text { Güney } \\
\text { Afrika }\end{array}$ & 4.35 & 56 & 53 \\
\hline
\end{tabular}

Kaynak: WEF, 2013: 13; 2014: 14. *2014-2015 endeksi 144 ülke, 2013-2014 endeksi ise 148 ülke için hesaplanmıştır.

2014-2015 Küresel Rekabet Gücü Raporu'ndan, küresel rekabet gücünü oluşturan unsurların teknolojik gelişme ilintili bileşenlerine bakıldığında, yükseköğretim, teknolojik düzey ve yenilik alt-endeksleri dikkat çekmektedir. Yükseköğretim ve eğitim alt-endeksine göre Finlandiya, Singapur, Hollanda, İsviçre ve Belçika; teknolojik düzey alt-endeksine göre Lüksemburg, İngiltere, İsveç, Norveç ve Hong Kong; yenilik alt-endeksine göre, Finlandiya, İsviçre, 
İsrail, Japonya ve ABD ilk beş sırada yer almaktadır. Türkiye, yükseköğretim (50.), teknolojik düzey (55.) ve yenilik (56.) alt-endeksleri açısından, küresel rekabet gücü sırlamasındaki yerine (45.) kıyasla daha gerilerde bulunmaktadır.

2013-2014 Küresel Rekabet Gücü Raporu'na göre, Türkiye, önceki yılda göstermiş olduğu önemli gelişmenin* ardından rekabetçilik skorunu düşürerek 44. sıraya gerilemiştir. Durumu diğer Avrupa ülkelerinin çoğundan daha iyi olmakla birlikte, bütçe açığı artışı ve iki haneli rakamlara yaklaşan enflasyon ile Türkiye'nin makroekonomik koşulları kısmen kötüleşmiştir. Yoğun yerel rekabet (15.) ile nitelenen Türkiye'nin canlı ticaret sektörü, yurtiçi piyasa genişliğinden (16.) önemli etkinlik kazançları sağlamıştır. Aynı zamanda, özellikle kara ve havayolu taşımacılığındaki gelişmiş altyapıdan (49.) yararlanılmıştır. Raporda, Türkiye'de rekabetçiliğin artırılması için, daha iyi temel eğitim ve sağlık (63.) ve daha iyi yükseköğrenim ve eğitim (74.) yoluyla insan kaynağının gelişmesi, işgücü piyasası etkinliği (124.) ve kamu kurumları etkinliği ile şeffaflı̆̆ının (67.) artırılmas1 gerekliliğine dikkat çekilmiştir (WEF, 2013: 29).

2014-2015 Küresel Rekabet Gücü Raporu'na göre Türkiye, etkinlik odaklı kalkınma aşamasından yenilik odaklı kalkınma aşamasına geçiş sürecinde olan ülkeler kategorisindedir. Küresel rekabet gücünü oluşturan unsurlar ve bunların alt bileşenleri detaylı olarak incelendiğinde, Türkiye'nin piyasa büyüklüğü (16.) ve mal piyasası etkinliği (43.) alanlarındaki rekabet gücünün, küresel rekabet gücüne kıyasla yüksek olduğu görülmektedir. Kurumlar (64.), makroekonomik istikrar (58.), sağllk ve temel eğitim (69.), yükseköğretim (50.), teknolojik düzey (55.) ve yenilik (56.) bileşenlerinin çoğunda Türkiye'nin rekabet gücü, küresel rekabet gücüne kıyasla düşüktür. Örneğin, Türkiye'nin yükseköğretim altbileşenlerinden yalnızca lise düzeyinde okullaşma oranları (28.) açısından rekabetçi üstünlügü varken geri kalan unsurlar açısından rekabetçi dezavantajı söz konusudur. Teknolojik düzey alt- bileşenlerinden, firma düzeyinde teknoloji adaptasyonu (37.), DYY ve teknoloji transferi (28.) ile geniş bant internet kullanıcı sayısı (40.) açısından rekabetçi üstünlük, geri kalan unsurlar açısından rekabetçi dezavantaj vardır. Yenilik alt-bileşenlerinden ise, yenilik kapasitesi (77.), bilimsel araştırma kurumlarının niteliği (64.), şirketler tarafından yapılan ar-ge harcama düzeyi (89.), ar-ge konusunda üniversite-sanayi işbirliği (61.) ve bilim adamı ve mühendis sayısı (59.) açısından rekabetçi dezavantaj söz konusudur (WEF, 2014: 368-369). Yine bu rapora göre, yönetici görüş anketleri ile saptanan Türkiye'de iş yapmada karşılaşılan en problemli 16 unsurdan ilk beşi, sırasıyla hantal bürokrasi, istikrarsız politika, düşük eğitimli işgücü, vergi oranları ve finansmana erişimdir.

Ülkelerin rekabetçiliğini karşılaştırmalı olarak değerlendirirken yararlanılabilecek bir diğer endeks de IMD tarafindan hesaplanan Dünya Rekabetçilik Skorbordu'dur. Ekonomik performans, kamu etkinliği, iş dünyası

* Küresel Rekabet Gücü Raporu 2012-2013'e göre Türkiye, diğer ekonomiler arasında rekabetçilik skorunu en çok artıran ülkelerden biri olmuş; 16 sıra birden hareket ederek 43. sıraya yükselmiştir. Ülke ekonomisi 2011 yılında \%8,4 oranında büyümüş ve KRE kapsamındaki birçok alanda önemli gelişmeler sağlamıştır. Ayrıntılı bilgi için bkz. WEF, 2012: 27,60 . 
etkinliği ve altyapı gibi faktörlerin dikkate alınması ile hesaplanan bu endeks çerçevesinde ülkelerin rekabet gücü sıralaması, Tablo-4'te, 2013 ve 2014 karşılaştırması ile sunulmaktadır.

Tablo-4: Dünya Rekabetçilik Skorbordu

\begin{tabular}{|c|c|c|c|c|c|c|c|}
\hline \multirow{2}{*}{ Ülke / Bölge } & \multirow{2}{*}{2014 Skor* } & \multicolumn{2}{|c|}{ Siralama* } & \multirow{2}{*}{ Ülke / Bölge } & \multirow{2}{*}{2014 Skor* } & \multicolumn{2}{|c|}{ Suralama* } \\
\hline & & 2014 & 2013 & & & 2014 & 2013 \\
\hline $\mathrm{ABD}$ & 100 & 1 & 1 & Şili & 62.5 & 31 & 30 \\
\hline İsviçre & 92.4 & 2 & 2 & Kazakistan & 62.5 & 32 & 34 \\
\hline Singapur & 90.9 & 3 & 5 & Çek Cumh. & 62.2 & 33 & 35 \\
\hline Hong Kong & 90.3 & 4 & 3 & \begin{tabular}{|l|} 
Litvanya \\
\end{tabular} & 62 & 34 & 31 \\
\hline İsveç & 85.8 & 5 & 4 & Letonya & 61.8 & 35 & 41 \\
\hline Almanya & 85.7 & 6 & 9 & Polonya & 61.7 & 36 & 33 \\
\hline Kanada & 85.4 & 7 & 7 & Endonezya & 59.5 & 37 & 39 \\
\hline Birleşik Ar. Em. & 84.8 & 8 & 8 & Rusya & 57.9 & 38 & 42 \\
\hline Danimarka & 84 & 9 & 12 & İspanya & 57.9 & 39 & 45 \\
\hline Norveç & 83.2 & 10 & 6 & Türkiye & 57.8 & 40 & 37 \\
\hline Lüksemburg & 82.1 & 11 & 13 & Meksika & 57.2 & 41 & 32 \\
\hline Malezya & 82 & 12 & 15 & Filipinler & 54.9 & 42 & 38 \\
\hline Tayvan & 81.2 & 13 & 11 & Portekiz & 54.4 & 43 & 46 \\
\hline Hollanda & 81.1 & 14 & 14 & Hindistan & 53.9 & 44 & 40 \\
\hline İrlanda & 80.3 & 15 & 17 & Slovak Cumh. & 53.3 & 45 & 47 \\
\hline İngiltere & 79.8 & 16 & 18 & \begin{tabular}{|l} 
İtalya \\
\end{tabular} & 52.8 & 46 & 44 \\
\hline Avustralya & 79.5 & 17 & 16 & Romanya & 52.8 & 47 & 55 \\
\hline Finlandiya & 78.1 & 18 & 20 & Macaristan & 52.5 & 48 & 50 \\
\hline Katar & 77.1 & 19 & 10 & Ukrayna & 50.8 & 49 & 49 \\
\hline Yeni Zelanda & 74.9 & 20 & 25 & Peru & 50.5 & 50 & 43 \\
\hline Japonya & 73.7 & 21 & 24 & Kolombiya & 49.2 & 51 & 48 \\
\hline Avusturya & 73.6 & 22 & 22 & Güney Afrika & 48.2 & 52 & 53 \\
\hline Çin & 73.2 & 23 & 21 & Ürdün & 47.7 & 53 & 56 \\
\hline İsrail & 73.2 & 24 & 19 & Brezilya & 46.7 & 54 & 51 \\
\hline İzlanda & 69.7 & 25 & 29 & \begin{tabular}{|l|} 
Slovenya \\
\end{tabular} & 46.2 & 55 & 52 \\
\hline G. Kore & 69.6 & 26 & 22 & Bulgaristan & 45.7 & 56 & 57 \\
\hline Fransa & 67.9 & 27 & 28 & Yunanistan & 42.2 & 57 & 54 \\
\hline Belçika & 66.5 & 28 & 26 & Arjantin & 39.5 & 58 & 59 \\
\hline Tayland & 64.9 & 29 & 27 & Hurvatistan & 38.9 & 59 & 58 \\
\hline Estonya & 64.3 & 30 & 36 & Venezüella & 34.2 & 60 & 60 \\
\hline
\end{tabular}

Kaynak: IMD, 2014: 8-9; 2013: 4-5. Not: *Rekabet Gücü siralamas1 2014 ve 2013 yilı için 60 ülkeyi kapsamaktadır.

2014 verilerine göre, ABD, İsviçre, Singapur, Hong Kong ve İsveç, dünya rekabetçilik liginde ilk beş sıradadır. ABD, 2013 ve 2014'te 1. sıradaki yerini korurken, Singapur 5. sıradan 3. sıraya yükselmiş; Türkiye ise, 57,8 skor ile 37. sıradan 40. sıraya gerileyerek bir önceki yıla göre rekabet gücünü düşürmüştür. Sıralamada dikkat çekici bir şekilde yükselerek diğer ülkeler karşısında rekabet gücünü artıran ülkeler, Almanya, Danimarka, Malezya, Yeni Zelanda, Estonya, 
Japonya, Letonya, İspanya ve Romanya; gerileyen ülkeler ise, Norveç, Katar, Litvanya, Polonya, Meksika, Filipinler ve Hindistan'dır.

Dünya Rekabetçilik Skorbordu 2014 verilerine göre, ilk sırada yer alan ABD'nin bu başarısı, daha yüksek istihdam düzeyi ile teknoloji ve altyapıdaki üstünlügüne dayanmaktadır. İsviçre (2.), Singapur (3.) ve Hong Kong (4.) ise, başarılarını, ihracat, şirketlerin etkinliği ve yenilik sayesinde sağlamışlardır. Japonya (21.), ulusal paranın değerindeki düşüklük nedeniyle rekabetçilik sıralamasındaki yerini iyileştirmiştir. Asya'da, Tayland (29.) bir önceki yıla göre rekabet gücünü düşürürken, Malezya (12.) ve Endonezya (37.) artırmıştır. Çin (23.), kısmen iş dünyasının sorunları nedeniyle, bir önceki yıla göre rekabetçilik sıralamasında gerilemiştir (IMD, 2015).

Dünya Rekabetçilik Skorbordu 2014'te, rekabetçilik endeksini oluşturan faktörlerden teknolojik gelişme ilintili olanlarına bakıldığında, teknolojik altyapı, bilimsel altyapı ve eğitim alt-faktörleri dikkat çekmektedir. Bunlardan teknolojik altyapı alt-faktörüne göre, Hong Kong, Singapur, ABD, Tayvan ve Malezya; bilimsel altyapı alt-faktörüne göre, ABD, Japonya, Almanya, İsviçre ve İsrail; eğitim alt-faktörüne göre, Danimarka, Singapur, Finlandiya, İsviçre ve Kanada ilk beş sırada yer almaktadır. Türkiye ise, teknolojik altyapı (52.) ve eğitim (53.) alt-faktörleri bakımından dünya sıralamasında, tüm faktörlerin içerildiği genel sıralamadaki konumuna (40.) kıyasla daha gerilerde yer alırken bilimsel altyapı (36.) açısından daha ileride bulunmaktadır (IMD, 2014: 24-25). Türkiye, imalat sanayi ihracatı içinde yüksek teknolojili ürünlerin payı (59.), kişi başına düşen bilgisayar sayısı (56.), mobil telefon aboneliği (56.), fikri mülkiyet hakları (54.), yenilik kapasitesi (51.), ortaöğretime kayıt oranı (51.) ve ortaöğretimde öğrenci başına öğretmen sayısı (55.) gibi alt-faktörler bakımından zayıf durumdadır (IMD, 2014: 252-253).

\section{SONUÇ VE DEĞERLENDİRME}

Üretim faktörlerinin etkinliği üzerinden maliyet, rekabet, ticaret ve refahın belirleyicisi olarak teknoloji, icat, taklit, transfer vb yollarla gelişmekte; yayılma, taşma, dışsallıklar vb kanallarla sürekli/dinamik/birikimli iktisadi sonuçlara kaynaklık etmektedir. Dünya ticaretinden daha yüksek pay, daha ileri düzeyde rekabetçi pozisyonu; bu da teknolojik gelişme bileşenlerinin uygun işlevini/katkısını gerektirmektedir.

Uluslararasi kurumlar tarafindan hesaplanan endeksler kullanılarak dünyada ve Türkiye'de teknolojik gelişmenin rekabetçilik üzerindeki etkileri bağlamında küresel görünümün ele alındığı bu çalışmada, kavramsal ve sayısal değerlendirmeler, teknolojik gelişme ilintili kanalların işleyişi ile ülkelerin rekabetçilik sıralamasındaki konumunun şekillenmekte olduğunu ve teknolojik gelişmeye daha az kaynak ayıran ülkelerin rekabetçilik sıralamasında daha gerilerde yer aldığını; daha fazla kaynak ayıran ülkelerin rekabetçilik sıralamasındaki konumunu iyileştirdiğini göstermektedir. 
Uzun dönemde verimlilik, rekabet gücü ve refah düzeyindeki artış, teknolojik gelişme ve yeniliklerle geliştirilebilmektedir. Gelişmekte olan ülkeler, mevcut teknolojileri kullanarak/içselleştirerek veya iyileştirmeler yaparak üretkenlik ve rekabet güçlerini artırabilir. Gelişmiş ülkeler ise, rekabetçi pozisyonlarını sürdürebilmek için yeni ürün ve süreçleri tasarlayarak hayata geçirmelidir. Yenilikçi iktisadi ortam bağlamında ar-ge için ayrılan kaynaklar ve özel sektör payının artırılması, nitelikli bilimsel araştırmaların yapılması ve bunların sanayiye uygulanabilmesi için, araştırma kurumları, üniversiteler ve özel sektör arasında kapsamlı bir işbirliği platformunun oluşturulması ve fikri mülkiyet haklarının korunduğu bir hukuk düzeninin varlığına ihtiyaç duyulmaktadır.

IMD ve WEF tarafindan hesaplanan küresel rekabetçilik endeksleri ve bunların teknoloji ilintili bileşenlerine göre, ABD, İsviçre, Singapur, Hong Kong gibi teknolojik gelişme ve yenilik ilintili göstergeler bakımından iyi konumdaki ülkelerin, küresel rekabetçilik sıralamasında da ön sıralarda yer aldığ 1 görülmektedir. Çalışmamızın "teknolojik gelişme ilintili kanalların işleyişi ile ülkelerin rekabetçilik sıralamasındaki konumunun şekillenmekte olduğunu" ifade eden argümanını destekleyen bu saptamalardan hareketle, ülkeler açısından küresel rekabet avantajının, öncelikle teknoloji geliştirme/kullanma kabiliyetini doğru şekillendirmekten geçtiği söylenebilir.

Türkiye'nin gerek küresel rekabetçilik sıralamasındaki yeri, gerekse teknolojik gelişme ve yenilikçilik alt-bileşenleri açısından konumu, benzer gelişme düzeyindeki ülkelerin gerisindedir. WEF Küresel Rekabetçilik Endeksi'nin yenilik alt-bileşenlerinden yenilik kapasitesi, bilimsel araştırma kurumlarının niteliği, şirketler tarafından yapılan ar-ge harcama düzeyi, ar-ge konusunda üniversite-sanayi işbirliği ve bilim adamı ve mühendis sayısı açısından rekabetçi dezavantajı olan Türkiye, IMD’nin Dünya Rekabetçilik Skorbordu'na göre de, benzer şekilde imalat sanayi ihracatı içinde yüksek teknolojili ürünlerin payı, kişi başına düşen bilgisayar sayısı, mobil telefon aboneliği, fikri mülkiyet hakları, yenilik kapasitesi, ortaöğretime kayıt oranı ve ortaöğretimde öğrenci başına öğretmen sayısı gibi alt-faktörlerde zayıf durumdadır ve bu alanları geliştirmeye ihtiyacı vardır. Bu bağlamda Türkiye'de, uzun vadeli stratejik yaklaşım çerçevesinde yenilikçi bir ortamın oluşturulması için, inovasyon, markalaşma, patent ve teknolojik gelişmeye ivme kazandırılmasına yönelik politikalar ivedilikle hayata geçirilmelidir.

\section{KAYNAKCA}

AIGINGER, K. (1997). "The Use of Unit Values to Discriminate between Price and Quality Competition", Cambridge Journal of Economics, 21(5): 57192.

AKTAN, C. C. (2009). "Rekabet Gücü Kavramı", www.canaktan.org/yenitrendler/yeni-rekabet kavram.htm, (12.09.2009) 
ARCHIBUGI, D. and MICHIE J. (1998). "Technical Change, Growth and Trade: New Departures In Institutional Economics", Journal of Economic Surveys, 12(3): 1-20.

BALASSA, B. (1965). "Trade Liberalization and Revealed Comparative Advantage", Manchester School of Economic and Social Studies, 33(2): 99-124.

BEIJE, P. (1998). Technological Change in the Modern Economy, Edward Elgar Publishing, Inc., United Kingdom.

CANTWELL, J. (2005). "Innovation and Competitiveness", (Eds.) FAGERBERG, J., MOWERY, D. C. and NELSON, R. R., The Oxford Handbook of Innovation, Oxford University Press Inc., New York.

DOSI, G. (1988). "Sources, Procedures, and Microeconomic Effects of Innovation", Journal of Economic Literature, 26(3): 1120-1171.

ERNST, D. and O'CONNOR, D. (1989). Technology and Global Competition, OECD, Paris.

FAGERBERG, J. (1988). "International Competitiveness", The Economic Journal, 98(391): 355-374.

GOMULKA, S. (1990). The Theory of Technological Change and Economic Growth, Routledge, London.

GREENHALGH, C., and ROGERS, M. (2010). Innovation, Intellectual Property and Economic Growth, Princeton University Press, United Kingdom.

GROSSMAN, G. M. and HELPMAN, E. (1989), "Product Development and International Trade, Journal of Political Economy, 97(6): 1261-1283.

GROSSMAN, G. M. and HELPMAN, E. (1991). Innovation and Growth in the Global Economy, MIT Press, Cambridge.

HOEKMAN, B. and JAVORCIK, B. S. (2006). "Lessons From Empirical Research on International Technology Diffusion Through Trade and Foreign Direct Investment", (Eds.) HOEKMAN, B., and JAVORCIK, B. S., Global Integration and Technology Transfer, The World Bank and Palgrave Macmillan, New York.

IMD (2013). Word Competitiveness Yearbook 2013, IMD World Competitiveness Center, Switzerland, http://www.conicyt.cl/wpcontent/uploads/ 2013/07/WCY_2013.pdf, (28.03.2015)

IMD (2014). Word Competitiveness Yearbook 2014, IMD World Competitiveness Center, Switzerland, http://www.conicyt.cl/wpcontent/uploads/ 2014/07/WCY-2014.pdf, (28.03.2015)

IMD (2015). 2014 World Competitiveness Yearbook Ranking, http://www.imd. org/news/2014-World-Competitiveness.cfm, (28.03.2015) 
JAFFE, A. B. (1986). "Technological Opportunity and Spillovers of R \& D: Evidence from Firms' Patents, Profits, and Market Value", The American Economic Review, 76 (5): 984-1001.

JONES, C. I. (2007). İktisadi Büyümeye Giriş, (Çev.) ATEŞ Ş. ve TUNCER İ., Literatür Yayınları, İstanbul.

KEESING, D. B. (1965). "Labor Skills and International Trade: Evaluating Many Trade Flows with a Single Measuring Device", The Review of Economics and Statistics, 47(3): 287-294.

KENEN, P. B. (1965). Nature, Capital, and Trade, The Journal of Political Economy, 73(5): 437-460.

KİBRİTÇİOĞLU, A. (1996). Uluslararası (Makro) İktisat - Okumalar, AÜ Siyasal Bilgiler Fakültesi Y., Ankara, http://econwpa.repec.org/eps/it/ papers/ 0509/0509008.pdf, (25.05.2015)

KONYA TİCARET ODASI (2006). Rekabet Gücü Endeksi ve Türkiye, KTO Yayınları, Konya.

KRUGMAN, P. (1979). A Model of Innovation, Technology Transfer, and the World Distribution of Income, The Journal of Political Economy, 87(2): 253-266.

LALL, S. (2000). Turkish Performance in Exporting Manufactures: A Comparative Structural Analysis, QEH Working Paper Series, QEHWPS47.

LALL, S. (2001). Competitiveness, Technology and Skill, Edward Elgar Publishing, Inc., USA.

LIESNER, H. H. (1958). "The European Common Market and British Industry", The Economic Journal, 68(270): 302-316.

LIU, S., FANG, Z., SHI, H. and GUO, B. (2010). Theory of Science and Technology Transfer and Applications, Taylor and Francis Group, New York.

MELICIANI, V. (2001). Technology, Trade and Growth in OECD Countries: Does Specialisation Matter?, Routledge, New York.

PORTER, M. E. (1990). The Competitive Advantage of Nations, A Division of Macmillan, Inc., New York.

POSNER, M. V. (1961). International Trade and Technical Change, Oxford Economic Papers, 13(3): 323-341.

REDDING, S. J. (2002). "Path Dependence, Endogenous Innovation, and Growth". International Economic Review, 43(4): 1215-1248.

ROLAND, A. (1992). "Theories and Models of Technological Change: Semantics and Substance", Science, Technology \& Human Values, 17(1): 79-100. 
ROSENBERG, N. (1982). Inside The Black Box: Technology and Economics, Cambridge University Press, New York.

SAGGI, K. (2006). "Foreign Direct Investment, Linkages, and Technology Spillovers", (Eds.) HOEKMAN, B., and JAVORCIK, B. S., Global Integration and Technology Transfer, The World Bank and Palgrave Macmillan, New York.

SEYIDOĞLU, H. (2007). Uluslararası İktisat Teori, Politika ve Uygulama, Güzem Can Yayınları. İstanbul.

SMITH, K. (1994). "New Directions in Research and Technology Policy: Identifying the Key Issues", STEP Report, The STEP-Group, Oslo.

TÜRKCAN, E. (2009). Dünya'da ve Türkiye'de Bilim, Teknoloji ve Politika, İstanbul Bilgi Üniversitesi Yayınları, İstanbul.

VERNON, R. (1966). "International Investment and International Trade in the Product Cycle", The Quarterly Journal of Economics, 80(2): 190-207.

WEF (2012). The Global Competitiveness Report 2012-2013, World Economic Forum, Genova, http://www3.weforum.org/docs/WEF_Global CompetitivenessReport_2012-13.pdf, (28.03.2015)

WEF (2013). The Global Competitiveness Report 2013-2014, World Economic Forum, Genova, http://www3.weforum.org/docs/WEF_Global Competitiveness Report_2013-14.pdf, (28.03.2015)

WEF (2014). The Global Competitiveness Report 2014-2015, World Economic Forum, Genova, http://www3.weforum.org/docs/WEF_Global CompetitivenessReport_2014-15.pdf, (28.03.2015)

YENTÜRK, N. (1991). "Teknoloji-Yoğun Mallar Açısından Türk Sanayiinin Rekabet Gücü, Gelişme Stratejileri ve Politika Önerileri”, 1991 Sanayi Kongresi Bildiriler Kitabı, Yayın No: 148-1, TMMOB Y., Ankara, (Kasım 1991): 247-260. 